\title{
First language attrition: the effects of English (L2) on Brazilian Portuguese VOT patterns in an L1-dominant environment
}

\author{
Atrito de língua materna: os efeitos do inglês (L2) nos padrões de VOT do português brasileiro \\ em um ambiente de L1 dominante
}

\section{Laura Castilhos Schereschewsky ${ }^{1}$, Ubiratã Kickhöfel Alves², Felipe Flores Kupske}

Undergraduate Research Assistant (Iniciação Cientifica Program) at Universidade Federal do Rio Grande do Sul (UFRGS), Brazil.

E-mail: castilhoslaura@gmail.com

Full-time professor at the Graduate Program in Linguistics - Universidade Federal do Rio Grande do Sul (U AGS), Brazil - and researcher at the e Tecnológico (CNPq).

Doctor in Applied Linguistics (UFRGS). Fulltime professor at the Department of Germanic Languages at Universidade Fed
ABSTRACT: Departing from a view of language as a Complex Adaptive System (CAS) (BECKNER et al., 2009; DE BOT et al., 2013), this paper discusses language attrition, by verifying possible attrition symptoms in Brazilian Portuguese (BP) among learners of English living in Brazil (an L1-dominant environment). We analyze the Voice Onset Time (VOT) of voiced and voiceless, bilabial and velar initial plosives in BP. There were 33 participants in the study (11 monolinguals of BP, 11 intermediate learners of English, and 11 advanced learners of English). All participants produced, individually, a reading task of words in BP. ANOVA tests demonstrated a significant difference among groups regarding the voiceless velar plosive, suggesting the occurrence of first language attrition in this segment. No significant differences between intermediate and advanced learners of English were found. These results, although suggesting that attrition is less common in contexts of L1 dominance, allow us to consider the possibility of occurrence of this phenomenon, providing evidence in favor of a bidirectional linguistic transfer in a bilingual setting.

Keywords: Complex adaptive systems; Language attrition; Voice Onset Time.

RESUMO: Partindo de uma visão de linguagem como um Sistema Adaptativo Complexo (CAS) (BECKNER et al., 2009; DE BOT et al., 2013), este trabalho discute o atrito linguístico. Seguindo esse trabalho, neste estudo, verificamos possíveis efeitos de atrito no português entre aprendizes de inglês residentes no Brasil (contexto de L1 dominante). Analisamos o VOT (Voice Onset Time) de plosivas bilabiais e velares, surdas e sonoras, em posição inicial de palavra do PB. Participaram do estudo 33 sujeitos, residentes em Porto Alegre. Os participantes foram divididos em 3 grupos (11 monolíngues do PB, 11 aprendizes de inglês de nível intermediário e 11 aprendizes avançados). Todos os participantes realizaram, individualmente, um teste de leitura de palavras do PB. Testes ANOVA demonstraram uma diferença significativa entre os grupos nas produções em português referentes à consoante velar surda, sugerindo o atrito nesse segmento. Não foram, entretanto, encontradas diferenças significativas entre aprendizes de nível intermediário e avançado. Os resultados, ainda que sugiram que o atrito seja menos comum em contextos de L1 dominante, não nos permitem descartar a possibilidade de ocorrência de tal fenômeno, provendo evidências de que, em contexto bilíngue, a transferência linguística possa ser bidirecional

Palavras-chave: Sistemas adaptativos complexos; Atrito linguístico; Voice Onset Time. 


\section{Introduction}

- - or years, it was believed that the age of first or second language - (henceforth, L1 and L2, respectively) learning was the main variable in speech production patterns, due to Lennenberg's (1967) Critical Period Hypothesis ( $\mathrm{CPH}$ ) for language acquisition. The $\mathrm{CPH}$ stated there was an ideal period to acquire a language; when it came to a second or third language, it suggested older learners were bound to present a foreign accent, since it would be impossible to achieve native-like production after this timeframe. Subsequent studies refuted this theory. Flege (1995, 2003, 2007), Best (2001), and Best \& Tyler (2007), for instance, propose that the cognitive mechanisms for modifying the phonetic-phonological system remain intact throughout life, pointing out that even a late learner may achieve native-like production under certain circumstances, even if it is established that one's L1 influences the L2.

Flege's (1995) Speech Learning Model suggested, as later corroborated by Best \& Tyler's (2007) Perceptual Assimilation Model-L2, that bilinguals cannot separate the phonetic categories of their L1 and L2 because they exist in the same phonological space, meaning they coexist and influence each other. This proposition is in accordance to Beckner et al. (2009) and De Bot et al.'s (2013) dynamic view of language, which proposes that language itself is a Complex Adaptive System (CAS). According to the authors, the complexity ${ }^{1}$ of language comes from it being a dynamic system consisting of numerous factors interacting with one another. They propose that language is also adaptive, because it is in constant change due to the speaker's experience. In their own words, "The structures of language emerge from interrelated

We use the terms 'Complex' and 'Dynamic' (and their variants) as a reference to a whole group of theories, which focus on the development of dynamic-complex systems as a function of time. patterns of experience, social interaction, and cognitive mechanisms" (BECKNER et al., 2009, p. 2).

In this way, bilinguals would experience a cross linguistic interaction between the two or more languages they speak, involved in multiple cognitive and linguistic levels. This means that, since the L1 has an influence on the L2, then the L2 may also influence the L1, which might lead to phoneticphonological attrition. Following this assumption, Kupske (2016) defines 'language attrition' as the force resulting from the contact of two or more bodies, in this case, two languages that interact, but do not stabilize, as they present a constant tendency for movement (KUPSKE, 2016, p. 39-40). In this sense, the process of first language attrition can be taken as the nonpathological loss of a bilingual individual's native way of speaking, led by contact with another language. Attrition as a phenomenon, on the other hand, refers to the time window between performing language as a native speaker, and facing a change in this performance. Thus, the interaction and influence between two or more languages might give rise to attrition.

Kupske (2016) studied the production of voiceless plosives in an initial position of Brazilian Portuguese (L1) and English (L2) by immigrants from Porto Alegre, Brazil, living in London, England, with different lengths of residence (LOR). In English (L2), there was an improvement in the production of the experimental group as the LOR increased, and even similar results to the native control group were found for the participants that had been residing in London for more than eight years. In the production of Portuguese (L1), attrition was found as the LOR increased, that is, the experimental group with the longest LOR, between eight and eleven years, presented values for BP that were statistically different from those produced by the monolinguals $(\mathrm{p}<.001)$. Based on this study, we aimed to verify if a similar phenomenon would surface in a context of L1 dominance, i.e. Brazilian learners of English with voiced plosives as well. Thus, in this paper, we investigate the production 
of plosive consonants by undergraduate students of English, born and living in Porto Alegre, Brazil. The main objective of this research study is to address BP (L1) attrition in the production of both voiced and voiceless bilabial and velar initial plosives by Brazilian learners of English (L2) (in a context of L1 dominance. By verifying the process of attrition not only in voiceless, but also in voiced plosives, we aim to discover whether this phenomenon can be noticeable in the development of different L2 VOT patterns (Positive VOT and Zero VOT, respectively).

This article is organized as follows. In section 2, we discuss a dynamic view of language, define the phenomenon of language attrition, and characterize VOT. In section 3, we describe the methodology and present our goals, hypotheses, the participants, materials and data collection procedures. In section 4 (Results and Discussion), we test our two hypotheses. In the final considerations, we discuss the phenomenon of attrition in an L1dominant environment, present the limitations of our study and provide some suggestions for future investigations.

\section{Theoretical Background}

\subsection{A dynamic view of Language}

According to Mercer (2013, p. 376), under the aegis of Complexity theories, there are innumerable approaches, such as Complex Adaptive Systems Theory, Dynamic Systems Theory, Chaos Theory, Network Theory, among others. Although there are, of course, differences between Complexityrelated theories, they all share some basic characteristics. Essentially, a dynamic perspective to language describes holistic, organic, and emerging systems that are composed of two or more interrelated systems, which may per se represent other complex/dynamic systems (MERCER, 2013). The barriers between systems are no longer clear, since a system is usually also part of other systems. All the elements of a given system are at the same time influencing and being influenced by all the others. Given the Butterfly Effect, behaviors or changes are not proportional to their causes and a small variation in a system, or a small input or new energy, can bring about great changes. Thus, as Paiva (2011) points out, every dynamic system is an open one and, as a consequence, energy can either enter or exit.

Mercer (2013) states that dynamic systems are self-structuring and selfsustaining, having the ability to adapt according to the environment and to the energy received or expended. These systems are subject to constant transformation. Willians (1997) defines complex systems as everything that moves, changes, or evolves over time. During this dynamic process, agents learn from each other, receive feedback, and gain experience. Thus, such systems are always dependent or sensitive to their initial conditions. In addition, dynamic systems are emergent. This means that, at a given point in time, the agents of these systems show interactions and collaborations that reveal the structure that governs their existence. This is the point at which the components create something larger than they would individually constitute; a structure without divisible components and whose connectivity is (should be) permanent (KUPSKE \& ALVES, 2016).

With regard to language development, it is known that the patterns of use, as pointed out, for example, by Usage-based Phonology (BYBEE, 2001), affect how a language is developed, used, organized, and even how it might vary during the life of an individual. These processes would thus be interdependent, according to Beckner et al. (2009). For these authors (Ibid. p. 1), the language as a complex system account has the following basic characteristics:

(i) The system consists of multiple agents that interact with each other, such as, for example, speakers in a given community. 
(ii) The system is adaptive, since the behavior of a speaker is based on his past interactions; however, such interactions, alongside current ones, are the factors that will delineate future interactions.

(iii) The behavior of a speaker is the consequence of competing factors, ranging from perceptual restrictions to social motivations.

(iv) The structures of a language emerge from the interrelated patterns of experience, social interaction and cognitive mechanisms/ processes.

Regarding the process of language development, under this prism, usage-based theories provide the complex theories with a direction (LARSEN-FREEMAN, 2013). These theories (e.g. BYBEE, 2001) advocate that one learns constructions and linguistic categories by engaging in organic communication through interpersonal and cognitive processes (SLOBIN, 1977). According to Beckner et al. (2009), development is a matter of complex and probabilistic analysis of language samples, which involves the estimation of the norms of a given speech community through limited samples derived from the experiences perceived by one's cognitive machinery, psychomotor capacities, as well as by the dynamics of social interaction itself.

Bybee (2001) and Heine \& Kuteva (2007) assume that grammar is, in a way, a replication process. People learn grammar by sequential processing, categorization, conventionalization, and inferential mechanisms. Therefore, grammar is seen as an uninterrupted process in all languages at all times. As far as the L2 is concerned, its constructions are closely related to frequency, recency and to the context of use itself. According to Larsen-Freeman (1997, p. 62), as in the L1, learners not only conform to the L2; they go further, by building new forms through analogies and recombination of patterns.

The linguistic system then results from dynamic cycles involving language use, linguistic change, perception and learning of the interactions between members of a speech community (ELLIS, 2008), as already indicated. The sequential processing, planning, and categorization skills enable learners to build a linguistic system. However, these skills per se do not demand the effective use of a language; people need to speak because of social interaction. Thus, although language is shaped by cognitive abilities, social life shapes language.

According to Haugen (2001), languages are constantly being redesigned by the interactions of their speakers in order to reflect the communicational experiences of the past, and to project current and future ones. Thus, any behavior of a speaker is the result of a range of competing factors, including physical as well as cognitive and social motivational factors. Over time, social interactions between speakers/agents produce linguistic changes at all levels, since there is a relationship between an individual and the environment, which provides patterns (GIBSON, 1979). From this perspective, linguistic constructions are developed by the engagement in real communicative acts through interpersonal communicative processes, in addition to the cognitive processes already mentioned. Linguistic knowledge is thus the result of an estimative analysis of the norms of a speech community through the cognitive apparatus, the human body and the dynamics of social interaction. In this perspective, grammar is constructed and possibly changed only via the use of the language in question. Therefore, the cognitive organization of a language is directly driven by the linguistic experience of a speaker. In this way, in a dynamic coloring, language development is a nonlinear and emergent process that is open, self-structuring, adaptive, unpredictable and sensitive to initial conditions and feedback (FINCH, 2001). According to Zimmer \& Alves (2014, p. 80), language learning can then be understood as emerging from the system that includes, among other variables, the cognitive apparatus, the body and the environment. 


\subsection{Interaction of phonetic categories}

Historically, even before Lenneberg's (1967) suggestion that a Critical Period might exist for the development of an L2, differences between the native and nonnative patterns were usually attributed to the process named "interference", that is, to the militancy of previously developed structures over those that are being acquired. In this sense, although far from categorical conclusions, there is no doubt that much effort has already been expended in understanding the influence of an L1 in the acquisition of an L2 (e.g. FLEGE, 1995; MACWHINNEY, 2002).

However, although the mechanisms in charge of the relationship between perception and production in language development are not explicit, Flege $(1995,2002,2007)$ points out that these mechanisms and processes applied to the development of L1 sounds, including category formation, remain intact throughout the lifespan, as pointed out in our introduction. Corroborating Flege (1995), Best and Tyler (2007) point out that speakers continue to ceaselessly refine their perceptions of speech sounds, including their own L1s. According to the authors, as already pointed out by Flege (1995), both L1 and L2 categories would coexist in the same phonetic-phonological space, and, therefore, would influence each other. In this sense, for a reasonable time, it is known that the final state of development of a bilingual cannot be equated with the sum of two monolingual states (e.g. GROSJEAN, 2001; COOK, 2006). Thus, a bilingual speaker will inherently differentiate him/herself from a monolingual as he/she access an integrated linguistic processing system, which implies a cross linguistic interaction between all languages involved in multiple cognitive and linguistic levels. Likewise, a recent body of research on the phonological-phonetic component points out that language transfer is clearly bidirectional (e.g. SANCIER \& FOWLER, 1997; FLEGE, 2007; CHANG, 2010; KUPSKE, 2016; KUPSKE \& ALVES, 2016). In other words, the
L2 also exerts force on the system of origin in the development process, a clear possibility to a dynamic view of language.

The effects of the L1-L2 interaction in bilinguals are already documented on cognitive processing (e.g. BIALYSTOK, 2009), on multi-level linguistic processing (e.g. VAN HELL \& DIJKSTRA, 2002), as well as on the mental lexicon (e.g. HERNANDEZ, BATES, \& AVILA, 1994), on sentence processing (e.g. CUTLER, HAWKINS \& GIJLIGAN, 1989), speech production (e.g. KUPSKE \& ALVES, 2016), among others. In this way, it becomes increasingly clear that bilingualism affects the mechanisms and strategies of both L2 and L1 processing (DUSSIAS, 2004), as well as the processing speed in both languages (HOPP, 2007), even though both languages are simultaneously developed in early childhood (WERKER \& BYERS-HEINLEIN, 2008).

Thus, there is evidence of the status of language as a dynamic system, susceptible to modifications that are guided by the new experiences of a speaker (BECKNER et al., 2009; KUPSKE \& ALVES, 2016). The premise that bilingual speakers may present a performance in each of their languages, which differs significantly from that of monolinguals', has been corroborated by a growing number of studies, both in the field of speech perception (e.g. BENKÍ, 2005; MAJOR; BAPTISTA, 2007), as well as production (e.g. SANCIER \& FOWLER, 1997; COHEN, 2004; FLEGE, 2007; LEE \& IVERSON, 2012; KUPSKE, 2016). Studies have also focused on different linguistic units, such as the vowel (e.g. FLEGE, 1987; GUION, 2003; CHANG, 2010); the consonant (e.g. FLEGE, 1987; FLEGE \& EEFTING, 1987; FLEGE \& HILLENBRAND, 1987; SANCIER \& FOWLER, 1997; HARADA, 2003; COHEN, 2004; FLEGE, 2007; LORD, 2008; CHANG, 2010; SIMON, 2011; KUPSKE \& ALVES, 2016; the syllable (CARAMAZZA et al., 1973); and on suprasegmental aspects (e.g. COLANTONI \& GURLEKIAN, 2004).

In this bidirectional perspective, according to Chang (2010, p. 64), the findings in the area of speech perception and production have suggested that it is rare, if not impossible, that a bilingual speaker's performance in at 
least one of his/her languages does not to differ from that of a monolingual speaker in some way. Also to the author, research indicates that L2-L1 influence will surface both in early bilinguals and in simultaneous or sequential adult bilinguals. It is also known that the L1 sounds tend to drift towards the closer L2 sounds. However, they may also drift in the opposite direction, so that certain contrasts are maintained in the phonetic-phonological space that includes both languages (KUPSKE, 2016).

Flege (2007) points out that there is an unequivocal interaction between the L1 and the L2 systems. When we retrieve two of the statements proposed in the Speech Learning Model (SLM - FLEGE, 1995), this possibility is clearer: (i) The SLM first points out that the acquisition of an L2 is not restricted by a Critical Period; and (ii) the capabilities required for a monolingual to acquire properties of the L1 are preserved for life and remain accessible to learners of any age, despite the possible effects of the different ages of onset of acquisition. The SLM (FLEGE, 1995) also points out that the categories that form both the L1 and the L2 are in the same phonological space (FLEGE, 2007), as already mentioned, and can then influence one another.

\subsection{Language attrition}

According to Köpke \& Schmid (2004), most people who have learned an L2 in the past, for instance, will consider themselves "attrited" after some time without using it. This means that they now present a lag in the L2 in some way, something they did not face in the past. Although this fascination is as old as the science of language itself, it is only in recent decades that a scientific knowledge has been built on this subject; however, it is still very limited (KUPSKE, 2016). Most of the research on L1 attrition is still concerned with the investigation of vocabulary loss and problems of lexical access; indeed, when asked about the extent to which they themselves are affected by attrition, most speakers will immediately remark those issues.
Yet, most studies testing these assumptions yielded no results concerning a dramatic lexical loss or problems of lexical access, nor substantially reduced speed of lexical retrieval (e.g. YILMAZ \& SCHMID, 2015).

As for grammar, there is a considerable body of studies analyzing to what extent specific characteristics of a language can be affected by language attrition (SCHMID, 2013). On the other hand, the field of phonetics and phonology - the focus of this study, to Schmid (2013, p. 03), is "dramatically under-researched". There are still few studies aiming to measure phonetic attrition (e.g. FLEGE, 1987; MAJOR, 1992; SANCIER \& FOWLER, 1997; KUPSKE, 2016; KUPSKE \& ALVES, 2016).

To Kupske (2016), L1 attrition, as taken in the present work, was established in the scientific community only in the last decade. For some time before this revolution in the area, which began in 1982, the field of language loss was interested in instrumental factors on linguistic change and linguistic death in communities facing language contact, such as second and third generation immigrants and minorities. These studies focused on the level of group/ community of speakers, as well as the socioeconomic factors that had an influence in linguistic change, shift or death.

In general, attrition can be defined as the decline in any language (L1, L2, or other language), ability, or part of it, in a healthy speaker (ECKE, 2004). L1 attrition can then be characterized in two possible ways: as a process or as a phenomenon (SCHMID, 2007). The definition of attrition as a process is somewhat simple: in general, L1 attrition can be taken as the nonpathological loss of an individual's native way of speaking (KÖPKE \& SCHMID, 2004). In other words, language attrition investigates the situation in which a speaker is no longer able to do something he/ she would previously do, and this loss in proficiency is not a result of brain deterioration, disease, or age. Thus, to Goral (2004), attrition refers to non-age-related losses, as several studies point out that some language skills may change with advancing age. 
According to this author (op. cit.), this type of language loss, which occurs in healthy aging, has also been described as attrition in the past, although today the focus of attrition studies is healthy bilingualism. Therefore, attrition reports the loss of a language by a change in the linguistic behavior of a speaker facing a scarce contact with the community where the language that gets attrited is spoken (SCHMID, 2013). In the same fashion, Kupske (2016) states that there are three main likely scenarios for this case: 1) when all contact with the attrited language was interrupted in an L2-dominant setting, there being no more linguistic input or organic communication; 2) when there is a great competition with other linguistic systems, as in the case of immigrants also in an L2-dominant environment; and 3) when advanced users of a given L2 face it on a constant basis, such as L2 teachers in an L1-dominant context (COHEN, 2004; LORD, 2008; CHANG, 2010).

Language attrition as a phenomenon is more difficult to be defined. Firstly, by understanding attrition as a process, one must predict two stages of an attrited speaker, the pre-attrition stage (A) and the attrition stage (B), and the space of time between $A$ and $B$ would refer to the attrition as a phenomenon. When it is a fact that Moment B is different from Moment A, the phenomenon of L1 attrition has been established.

As for Major (2010), L1 attrition can be defined as any change in production and/or perception that is not found among typical speakers of the same language or dialect. To Schmid (2013), the term 'attrition' applies when a bilingual reaches a high level of L2 proficiency by using it with great frequency and regularity and, as a consequence, also presents a greater variability in form and in how lexical, grammatical or phonetic properties are applied in the L1. According to Cook (2006), this phenomenon can happen at various levels, from small modifications in the phonetic production level, to a temporary or permanent L1 loss - linguistic death. This process is well evidenced in speakers who have migrated to countries where an L2 is dominant (KÖPKE \& SCHMID, 2004).
In addition, some scholars will differentiate structural language loss from functional loss. Köpke (2004), in this sense, defines language attrition as the loss of structural aspects of a language, such as changes in form. The change of functional aspects would be related to Language Shift, as, for example, in cases where there is a gradual substitution of one language for another with respect to its use (that is, changes in the role/function that an L1 holds in the life of an individual). In this study, following Kupske (2016), L1 attrition is defined as non-pathological and not related to the healthy aging structural loss of an individual's mother tongue.

\subsection{Voice Onset Time - the phonetic aspect investigated}

Voice Onset Time (VOT) is defined as the time interval regarding the delay of the vibration of the vocal folds between the release of a plosive consonant and the start of the vocalic vibration of the segment following that consonant (LISKER \& ABRAMSON, 1964; LADEFOGED, 2001; COHEN, 2004). There are three main VOT patterns in the known languages in the world, as can be seen in Figure 1:

- Zero VOT: vocal fold vibration starts immediately after the release of the plosive;

- Positive VOT: vocal fold vibration starts with a delay after the release of the plosive, this delay being a moment of voiceless aspiration;

- Negative VOT: vocal fold vibration starts before the release of the plosive, in a moment referred to as pre-voicing.

In BP, the voiced plosives $/ \mathrm{b} /, / \mathrm{d} /$ and $/ \mathrm{g} /$ are produced with a negative VOT (pre-voicing), whereas voiceless plosives are produced with a zero VOT. English, on the other hand, presents voiced plosives produced mostly with a zero VOT, whereas voiceless plosive are produced with a positive VOT, being therefore aspirated: $\left[\mathrm{p}^{\mathrm{h}}\right],\left[\mathrm{t}^{\mathrm{h}}\right]$, and $\left[\mathrm{k}^{\mathrm{h}}\right]$. In other words, the two languages show different VOT patterns. 
Figure 1 - Onset of periodicity of the following segment (vocal folds vibration) described by Lisker \& Abramson (1964), represented by dented line

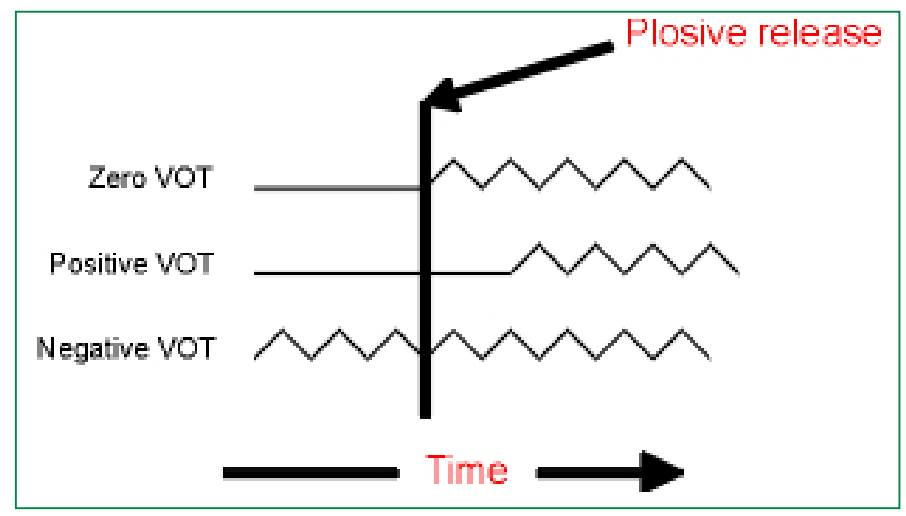

Fonte: Cohen (2004, p. 5).

Cohen (2004) was the first Brazilian researcher who studied the bidirectional phonetic transfer of Positive VOT found in word-initial voiceless plosives produced by Brazilian speakers ${ }^{2}$ of English, and found increased VOT values approximating those found in the literature on L1 English. Following that, the investigation conducted by Kupske (2016) studied the production of word-initial voiceless plosives in Southern Brazilian Portuguese (L1) and in Standard Southern British English (SSBE - L2) by immigrants from Porto Alegre, Brazil, living in London, England, with different lengths of residence (LOR 0-3, 4-7, and 8-11 years). For the production of SSBE (L2), the data showed an increase in the VOT values for all plosive consonants according to the LOR. Similar values to those produced by the SSBE monolinguals were found in the LOR 8-11 group, regardless of the place of articulation of the target

2 Cohen also describes his participants as "advanced users of English", and most of them were English teachers. consonant. For the production of BP (L1), the author verified the existence of first language attrition in the LOR 8-11 group when compared to the Brazilian control-group for all the analyzed BP consonants. Kupske (op. cit.) also found attrition for [t] and [k] in the LOR 4-7 group, and a higher variability in the productions of the LOR 0-3 group (suggesting a possible beginning of the attrition process). In the present study, in a similar fashion to Cohen (2004), we investigate first language attrition among Brazilian learners of English living in Brazil, in an L1-dominant environment. We innovate in investigating not only the production of voiceless stops, but also voiced stops in initial position, as we aim to verify if BP pre-voiced stops can also be affected by the Zero VOT pattern found in initial /b/ and /g/ in English.

\section{Methodology}

\subsection{Objectives and hypotheses}

Based on these previous studies, especially on Kupske (2016), we investigated if the phenomenon of language attrition would occur in an L1dominant context, as well as with voiced plosives. Thus, the main objective of this research study is to address first language attrition (Portuguese-L1) in the production of both voiced and voiceless initial plosives by Brazilian learners of English born and raised in Porto Alegre, Brazil, in an L1-dominant setting.

As for the specific goals, we aim to:

1) Investigate the occurrence of first language attrition by verifying if there is a difference among the VOT values in BP (both negative and zero VOT patterns) produced by BP monolinguals, intermediate and advanced learners of English, all of them born and raised in Porto Alegre, Brazil. 
HYPOTHESIS 1. There will be significant differences in the mean BP VOT values between the monolingual and the advanced learners: the BP VOT values produced by the monolinguals will be significantly shorter than the ones produced by the advanced learners; there will be no significant difference between the monolinguals and the intermediate learners.

2) Verify the role of L2 proficiency in first language attrition, by investigating if the VOT values in L2 English are close to the L1 English values, and if the two groups (intermediate and advanced learners) show different VOT values in each language (BP and English).

Hypothesis 2. There will be significant main effects of proficiency (intermediate and advanced) and language (Portuguese and English), as well as an interaction between these variables, as the difference between the VOT values in BP and English is smaller in the Intermediate group.

In other words, with our first goal, we aim to find differences among the three groups in their productions of BP. These differences may be suggestive of language attrition, but they are not enough for us to say that language attrition is taking place in view of the learners' L2 proficiency. With our second goal, we aim to show that there is a difference in the two language systems produced by the learners, and that language proficiency plays a role in this difference.

\subsection{Participants}

There were three groups of participants in this study, each with 11 informants, adding up to 33, all aged between 18 and 53 years (M: 22.36; DP: 3.4 ) at the time of the data collection ${ }^{3}$. They were all born and raised in Porto Alegre - Rio Grande do Sul, meaning they spent their period of first language

\footnotetext{
3 This research study was approved by the Ethics Committee at Universidade Federal do Rio Grande do Sul - Protocol number 648.674.
}

development in this area. The first group consisted of 11 monolingual speakers of Brazilian Portuguese (henceforth called the 'monolingual group'), as we consider 'monolingual' a person who has no proficiency in any other language, being unable to communicate and/or comprehend other languages.

The remaining 22 participants were bilinguals in Brazilian Portuguese (L1) and English (L2), taking the first semester of the Languages and Linguistics major at Universidade Federal do Rio Grande do Sul. Bilingual participants were selected and separated into two groups, according to their level of proficiency in English. Those who scored levels B1 and B2 in the Oxford Online Placement Test ${ }^{4}$ (PURPURA, 2007) were considered to be intermediate learners of English (henceforth called the intermediate group'). The other participants scored levels C1 and C2 and were considered to be advanced learners of English (henceforth called the 'advanced group').

\subsection{Materials and data collection}

The corpus consisted of two groups of words, one in Brazilian Portuguese, and one in English. The stimuli in BP were presented in individual sessions to the three groups of participants in a PowerPoint slide presentation, each slide containing a single word, with 40 tokens and 20 types, 12 target words and 8 distractors, all randomly repeated twice. All participants were asked to read the slides aloud while being audio recorded. The target words were all existing disyllabic words with a plosive consonant in word-initial position, 3 of them with /p/, 3 with $/ \mathrm{k} /, 3$ with $/ \mathrm{b} /$, and 3 with /g/, all followed by the high vowel /i/ and presenting a CV-CV phonetic structure, with the sole exception of guia (CV-V) ${ }^{5}$. The complete list of target words can be seen in

\section{Table 1.}

${ }^{4}$ Oxford Placement Test Online (PURPURA, 2007), available on: <www.oxfordenglishtesting.com>.

5 It is important to note that residents of Porto Alegre tend to palatalize / $t /$ and /d/ before the high vowel

[i]. Therefore, words like tia and dia are pronounced as [t $\mathrm{t}[\mathrm{i} e]$ and [dzie], with initial affricates instead of plosive consonants. For this reason, /t/ and / d/ were not included in the data collection. 
Table 1 - Target stimuli in BP

\begin{tabular}{cccc}
\hline$/ \mathbf{p} /$ & $/ \mathbf{k} /$ & $/ \mathbf{b} /$ & $/ \mathbf{g} /$ \\
pino & quina & bica & guizo \\
pico & quibe & bico & guisa \\
pira & quilo & bile & guia \\
\hline
\end{tabular}

The stimuli in English were presented to the two groups of bilingual participants in the same conditions after the data collection of the stimuli in BP. The data collection in English took place after a time interval of five minutes $^{6}$, and the data collection instrument contained 56 tokens and 28 types (18 target words and 10 distractors, all randomly repeated twice). This part of the data collection session was conducted in English. The target words were all existing monosyllabic words, also with a plosive consonant in word-initial position, 3 containing /p/, 3 with /t/, 3 with /k/, 3 with /b/, 3 with $/ \mathrm{d} /$, and 3 with $/ \mathrm{g} /$, all followed by the $/ \mathrm{i} /$ and $/ 1 /$ vowels ${ }^{7}$. The data collected with the $/ \mathrm{t} /$ and $/ \mathrm{d} /$ plosives were later excluded from the analysis due to the impossibility of comparison with the BP data. The complete list of target words in English can be seen in Table 2.

Table 2 - Target stimuli in English

\begin{tabular}{cccc}
\hline$/ \mathbf{p} /$ & $/ \mathbf{k} /$ & $/ \mathbf{b} /$ & $/ \mathbf{g} /$ \\
peer & kit & beer & gill \\
pit & keel & bit & git \\
pee & kill & bee & gear \\
\hline
\end{tabular}

${ }^{6}$ We recognize that an ideal setting for data collection would imply different days for the collection in each one of the languages involved in the study (cf. Kupske, 2016), but due to operational arrangements, this was not possible. Despite this limitation, we assured that some time span between the collections in the two languages was respected, so that recency effects could be controlled.

7 Yavas (2008) verified that the VOT values are higher when plosives are followed by those vowels, so we selected a corpus in this condition in both languages, aiming at higher VOT values that would allow we selected a corpus in this condition

\subsection{Analyses}

After the data were collected, we ran an acoustic analysis with Praat version 5.3.55 (BOERSMA \& WEENINK, 2015). The VOT value of each word was entered in milliseconds into five Excel tables, divided by language and then by level of proficiency. Negative VOTs (pre-voicing) were measured from the moment when vocal fold vibration became visible in the spectrogram, up to the burst of the voiced plosive. Positive VOTs were measured from the moment of the burst of the plosive to the beginning of the vocal fold vibration of the following vowel.

The statistics were run on SPSS (version 18). We carried out KolmogorovSmirnov and Shapiro-Wilk tests to verify the normality of the distributions (normal distribution, $\mathrm{p}>.05$ ), allowing us to run parametric tests.

\section{Results and Discussion}

\subsection{Productions in Brazilian Portuguese}

Table 3 shows the mean VOT values of both voiceless and voiced plosives by the three groups of participants in the production task conducted in BP.

Table 3 - Mean VOT values produced in the task in BP

\begin{tabular}{lcccc}
\hline & [p] & {$[\mathbf{k}]$} & {$[\mathbf{b}]$} & {$[\mathbf{g}]$} \\
& Mean (SD) & Mean (SD) & Mean (SD) & Mean (SD) \\
Monolinguals & $13.19 \mathrm{~ms}$ & $54.46 \mathrm{~ms}$ & $-95.77 \mathrm{~ms}$ & $-73.98 \mathrm{~ms}$ \\
& $(4.64)$ & $(13.50)$ & $(16.20)$ & $(22.89)$ \\
Intermediates & $14.03 \mathrm{~ms}$ & $76.56 \mathrm{~ms}$ & $-93.99 \mathrm{~ms}$ & $-79.20 \mathrm{~ms}$ \\
& $(6.76)$ & $(11.64)$ & $(17.48)$ & $(17.56)$ \\
Advanced & $15.28 \mathrm{~ms}$ & $71.80 \mathrm{~ms}$ & $-90.20 \mathrm{~ms}$ & $-71.80 \mathrm{~ms}$ \\
& $(4.45)$ & $(13.04)$ & $(24.86)$ & $(14.05)$ \\
\hline
\end{tabular}


Although the results shown in Table 3 seem similar, one-way ANOVA tests were conducted and showed a significant difference in the VOT values for $[\mathrm{k}]$ only, $\mathrm{F}(2,30)=9.152, \mathrm{p}=.001$ Post-hoc tests with Bonferroni correction showed a significant difference between the Monolingual and Intermediate groups ( $\mathrm{p}=.001)$, and also a significant difference between the Monolingual and Advanced groups $(\mathrm{p}=.010)$. However, no significant difference between the Intermediate and Advanced groups $(p=1.000)$ were found. This means that, although the bilingual groups differed from the monolinguals in the production of $/ \mathrm{k} /$, they did not differ between themselves. The other consonants did not present significant differences among the three groups (for $[\mathrm{p}], \mathrm{F}(2,30)=.419, \mathrm{p}=.661$; for $[\mathrm{b}], \mathrm{F}(2,30)=.224, \mathrm{p}=.800$; and for [g], $\mathrm{F}(2,30)=.464, \mathrm{p}=.633$.

These results allow us to say that $\mathrm{H} 1$ was only partially confirmed. Firstly, significant results were found only in one of the ANOVAS, the one concerning the velar plosive $/ \mathrm{k} /$, whose VOT values approach those found among native speakers of English. Although a significant difference has been found in the ANOVA, no significant differences were found between the VOT values produced by intermediate and advanced learners. Indeed, as far as descriptive VOT values are concerned, the average VOT values presented by the intermediate participants outnumber those produced by the advanced learners. Therefore, while the productions of BP [k] might differ among monolinguals and bilinguals, they do not differ according to the bilinguals' proficiency level.

\subsection{Productions in English}

Table 4 shows the mean VOT values in English produced by the bilinguals, and Table 5 compares the mean VOT values in English and BP of both voiceless and voiced plosives by the bilingual groups of participants, both intermediate and advanced learners.

Table 4 - Mean VOT values produced in the task in English

\begin{tabular}{lcccc} 
& [p] & {$[\mathrm{k}]$} & {$[\mathrm{b}]$} & {$[\mathbf{g}]$} \\
& Mean $(\mathbf{S D})$ & Mean $(\mathbf{S D})$ & Mean $(\mathbf{S D})$ & Mean $(\mathbf{S D})$ \\
\multirow{2}{*}{ Intermediates } & $23.20 \mathrm{~ms}$ & $87.86 \mathrm{~ms}$ & $-83.85 \mathrm{~ms}$ & $-73.47 \mathrm{~ms}$ \\
\multirow{2}{*}{ Advanced } & $(11.63)$ & $(22.90)$ & $(23.29)$ & $(21.92)$ \\
& $17.96 \mathrm{~ms}$ & $74.29 \mathrm{~ms}$ & $-92.83 \mathrm{~ms}$ & $-69.47 \mathrm{~ms}$ \\
& $(7.22)$ & $(15.13)$ & $(23.12)$ & $(16.88)$ \\
\hline
\end{tabular}

Table 5 - Mean VOT produced by the bilinguals in the tasks in BP and English

\begin{tabular}{|c|c|c|c|c|c|c|c|c|}
\hline & $\begin{array}{c}{[p]-B P} \\
\text { Mean (SD) }\end{array}$ & $\begin{array}{c}\text { [p] - En } \\
\text { Mean (SD) }\end{array}$ & $\begin{array}{c}{[\mathrm{k}]-\mathrm{BP}} \\
\text { Mean (SD) }\end{array}$ & $\begin{array}{c}{[\mathrm{k}]-\text { En }} \\
\text { Mean (SD) }\end{array}$ & $\begin{array}{c}{[\mathrm{b}]-\mathrm{BP}} \\
\text { Mean (SD) }\end{array}$ & $\begin{array}{c}{[\mathrm{b}]-\text { En }} \\
\text { Mean (SD) }\end{array}$ & $\begin{array}{c}{[\mathrm{g}]-\mathrm{BP}} \\
\text { Mean (SD) }\end{array}$ & $\begin{array}{c}{[g]-\text { En }} \\
\text { Mean (SD) }\end{array}$ \\
\hline Intermediates & $\begin{array}{c}14.03 \mathrm{~ms} \\
(6.76)\end{array}$ & $\begin{array}{c}23.20 \mathrm{~ms} \\
(11.63)\end{array}$ & $\begin{array}{c}76.56 \mathrm{~ms} \\
(11.64)\end{array}$ & $\begin{array}{c}87.86 \mathrm{~ms} \\
(22.90)\end{array}$ & $\begin{array}{c}-93.99 \mathrm{~ms} \\
(17.48)\end{array}$ & $\begin{array}{c}-83.85 \mathrm{~ms} \\
(23.29)\end{array}$ & $\begin{array}{c}-79.20 \mathrm{~ms} \\
(17.56)\end{array}$ & $\begin{array}{c}-73.47 \mathrm{~ms} \\
(21.92)\end{array}$ \\
\hline
\end{tabular}


By means of verifying the role of L2 proficiency in language attrition, we then conducted mixed-ANOVA tests in order to investigate main effects of proficiency and language and an interaction between these two variables. For $[\mathrm{p}]$, we found a significant main effect of language, $F(1,20)=15.345$, $\mathrm{p}=0.001$, and also a significant interaction between language and proficiency, $\mathrm{F}(1,20)=4.606, \mathrm{p}=.044$, but no significant effect of proficiency group, $\mathrm{F}$ $(1,20)=.431, p=.519$. We then conducted post-hoc tests (with Bonferroni correction) to find the intra and inter-group results. There was a significant difference in language within the Intermediate group, $\mathrm{T}(10)=4.517$, $\mathrm{p}=0.001$, but not within the Advanced group, $\mathrm{T}(10)=1.195, \mathrm{p}=.260$. As to the inter-group comparisons, there was no significant difference either in Portuguese, $\mathrm{T}(20)=-.514, \mathrm{p}=.613$, or in English, $\mathrm{T}(20)=1,269, \mathrm{p}=.219$. This can be easily noticed in the descriptive data shown in Table 5, as VOT values produced by advanced learners for [p] did not approach those values found among native speakers, and were also lower than the values produced by the intermediate learners. It remains to be said, however, that [p] was the only consonant in which an interaction between language and proficiency was found. For this consonant, while the intermediate group produced higher VOT values in English, very similar values were found in BP, with intermediate learners with slightly lower VOT values. These VOT values, still lower than those found among native speakers, do not seem to allow for L1 attrition, as for the non-significant result found in the verification of the first hypothesis showed.

The other three plosive consonants presented different results. The velar plosive deserves attention, as, based on the results of the tests run to test H1, this was the only consonant whose VOT values have shown attrition. As for this consonant, there was only a marginal main effect of language, $F$ $(1,20)=4.218, p=.053$, no significant main effect of group, $F(1,20)=2.278$, $\mathrm{p}=.147$, and no language-proficiency interaction, $\mathrm{F}(1,20) 1.721, \mathrm{p}=.204$.
Once again, intermediate learners presented higher descriptive VOT values than advanced participants (though this difference did not prove significant), but both groups presented descriptive values that approached those employed by native speakers of the language, which is an additional factor that allows us to suggest that attrition is taking place in this consonant. It is also interesting that VOT values in BP were higher among intermediate learners - this should not be surprising as we assume attrition is taking place, given that these learners present higher descriptive values of VOT in English.

As for the voiced plosives, for $[\mathrm{b}]$, there was a significant main effect of language, $F(1,20)=4.641, p=.044$, but no significant main effect of group, $\mathrm{F}(1,20)=.078, \mathrm{p}=.783$, and also no interaction between language and proficiency. Finally, the results for [g] did not show a significant main effect of language, $F(1,20)=1.014, p=.326$, nor of group, $F(1,20)=.779, p=.388$, and there was no significant interaction between language and group either, $\mathrm{F}(1,20)=.179, \mathrm{p}=.676$. These results for the voiced stops showed that participants still produce pre-voicing to characterize voiced stops in English, and do not seem to be developing the Zero VOT pattern to account for this pattern. This might be considered an expected tendency, as pre-voiced consonants are also produced variably in English. It might be the case that learners do not find it mandatory to focus on this cue, as the simple transfer from their L1 pattern may be useful in characterizing voiced stops in the target language. A similar tendency was found in Simon \& Leuschner (2010), with Dutch learners of English and German. Furthermore, it might be the case that learners have not even received a reasonable amount of positive evidence exhibiting Zero VOT in the production of [b] and [g], given that they have had classes with teachers/professors who share their L1 system and, therefore, need not have learned the target pattern in order to be intelligible in the target language. 
Given the results presented above, we can affirm that $\mathrm{H} 2$ was only partially corroborated. In fact, there was no consonant in which main effects of proficiency, language, and an interaction between these two variables were found. It remains to be said that both groups of bilinguals tended to present very similar descriptive VOT values, with a slight advantage shown by intermediate learners.

Taken as a whole, the verification of the two hypotheses in this section allows us to say that attrition might have taken place only in the production of [k]. In the next section, we propose some possible explanations for this fact.

\section{Final considerations}

Departing from a dynamic view of language, in this paper we investigated the process of language attrition concerning the production of Brazilian Portuguese initial plosives by learners of English studying and residing in Brazil. Our study was innovative in the sense that (i) it investigated Brazilian learners in an L1-dominant environment in two different proficiency levels (intermediate and advanced); (ii) it investigated the production of both voiceless (BP: Zero VOT; English: Positive VOT) and voiced (BP: Negative VOT; English: Zero Negative VOT) stops in word-initial position.

Our results allowed us to suggest the presence of L1 attrition only in the production of the velar consonant / k/. Given these results, it is relevant to consider why this seems to be the only consonant allowing for attrition. Firstly, a variety of studies (GEWEHR-BORELLA, 2010; FRANÇA, 2011; SCHWARTZHAUPT, 2013; M. ALVES, 2015; ALVES \& ZIMMER, 2015; KUPSKE, 2016) has indicated that the velar plosive tends to present larger VOT values (is "semi-aspirated", cf. M. Alves, 2015) in Southern Brazilian Portuguese. This fact may contribute to helping learners reach target VOT values in their
L2, unlike what happened with the bilabial plosive, whose VOT length did not reach target values. As the velar plosive is the first consonant whose target VOT values are achieved, it is likely that language attrition will firstly take place in this segment.

As for the voiced stops, even though a main effect of language has been found for [b], it seems that learners have not learned a new VOT pattern in the production of $[\mathrm{b}]$ and $[\mathrm{g}]$. As already mentioned, it might be the case that the development of a new VOT pattern does not prove necessary for intelligibility at all, as pre-voiced plosives are found variably in the target language. Given the fact that a new pattern does not seem to have been learned, there is no opportunity for attrition to take place.

It is also important to mention that no main effect of group was found when intermediate and advanced learners were tested in the Mixed ANOVA. In fact, an observation of the descriptive data in Table 5 shows that, in most cases, intermediate learners outperformed the advanced students. These results cast some doubt on the level of proficiency of the participants in this study. Although all participants sat for a proficiency test, they were all taking the same course level at university, and it might be the case that multiple-choice tasks do not reflect the learners' ability and experience in the target language. Besides, with regard to the phenomenon of L1 attrition, it proves important to investigate learners' experience with the second language. In this sense, language experience questionnaires, such as the ones employed in Kupske (2016) and Scholl (2016), might prove a better tool in the investigation of attrition. These questionnaires allow for a clearer picture of the participant's language background, as well as a holistic mapping of the participants' experience, attitudes and motivation, among other variables that have an impact on language attrition (OPTIZ, 2011). In a future study, with participants in different degrees of English tuition, we aim to investigate the role of these variables. 
Even though attrition effects have been found for one consonant only, the results of the present study have important theoretical implications, as we have shown that attrition, albeit discretely, may also occur in an L1dominant environment. Most importantly, these results provide evidence to the claim that both the L1 and the L2 systems are found in the very same phonological space, and that language systems are adaptive in such a way that not only do they have influence on, but they also suffer the influence of one another.

Language development, as a dynamic system, is sensible and dependent on the initial conditions of the process; therefore, the learning of a new language system is the result of the previous systems involved. Due to its adaptivity and openness, development conjointly affects whatever previous language(s) that has been learned. This might induce first language attrition, as suggested by the production of the BP velar plosives in this study.

\section{References}

ALVES, Mariane Antero. Estudo dos parâmetros acústicos relacionados à produção das plosivas do português brasileiro na fala adulta: análise acústico-quantitativa. 2015. $253 \mathrm{fl}$. Tese (Doutorado em Letras) - Universidade Federal de Santa Catarina, Florianópolis, 2015.

ALVES, Ubiratã Kickhöfel; ZIMMER, Márcia Cristina. Percepção e produção dos padrões de VOT do inglês por aprendizes brasileiros: o papel de múltiplas pistas acústicas sob uma perspectiva dinâmica. Alfa - Revista de Linguística, v. 59, n. 1, p. 157-180, 2015.

BECKNER, Clay; BLYTHE, Richard; BYBEE, Joan; CHRISTIANSEN, Morten H.; CROFT, William; ELLIS, Nick C.; HOLLAND, John; KE, Jinyun; LARSEN-FREEMAN, Diane; SCHOENEMANN, Tom. Language is a complex adaptive system: position paper. Language Learning, v. 59, n. 1, p. 1-26, 2009.

BENKÍ, José R. Perception of VOT and first formant onset by Spanish and English speakers. In COHEN, James (Org.). Proceedings of the 4th International Symposium on Bilingualism. Sommerville: Cascadilla Press, 2005. p. 240-248.
BEST, Catherine T. American listeners' perception of nonnative consonant contrasts varying in perceptual assimilation to English phonology. Journal of the Acoustical Society of America, v. 1097, p. 775-794, 2001.

BEST, Catherine; TYLER, Michael. Nonnative and second-language speech perception: Commonalities and complementarities. In: MUNRO, Murray; BOHN, Ocke-Schwen (Org.). Language experience in second language speech learning: The role of language experience in speech perception and production. Amsterdam: John Benjamins, 2007. p. 13-34.

BIALYSTOK, Ellen. Metalinguistic aspects of bilingual processing. Annual Review of Applied Linguistics. v. 21, n. 1, p. 169-181, 2009.

BOERSMA, Paul; WEENINK, David. PRAAT: Doing Phonetics by Computer, 2015. Available in: http://www.fon.hum.uva.nl/praat/

BYBEE, Joan. Phonology and Language Use. Cambridge: Cambridge Univ. Press., 2001.

CARAMAZZA, Alfonso; YENI-KOMSHIAN, Grace, ZURIF, Edgar B.; CARBONE, Ettore, The acquisition of a new phonological contrast: the case of stop consonants in FrenchEnglish bilinguals. Journal of the Acoustical Society of America, v. 54, n. 2, p. 421-428, 1973. https://doi.org/10.1121/1.1913594

CHANG, Charles Bond. First language phonetic drift during second language acquisition. 2010. 243 fl. Tese (Doutorado) - University of California, Berkeley, 2010.

COHEN, Gustavo. The VOT dimension: a bi-directional experiment with English and Brazilian-Portuguese stops. 2004. 70 fl. Dissertação (Mestrado em Letras) - Universidade Federal de Santa Catarina, Florianópolis, 2004

COLANTONI, Laura; GURLEKIAN, Jorge. Convergence and intonation: Historical evidence from Buenos Aires, Spanish. Bilingualism: Language and Cognition, v. 7, n. 2, p. 107-119, 2004. https://doi.org/10.1017/S1366728904001488

COOK, Vivian. Introduction: The Changing L1 in the L2 User's Mind. Effects of the Second Language on the First. Clevedon, Buffalo, Toronto, Sydney: Multilingual Matters, 2006. p. 1-18.

CUTLER, Anne; HAWKINS, John A.; GIJLIGAN, Gary. The suffixing preference: a processing explanation. Linguistics, v. 23, p. 723-758, 1989.

DE BOT, Kees; LOWIE, Wander; THORNE, Steven L.; VERSPOOR, Marjolijn. Dynamic Systems Theory as a comprehensive theory of second language development. Contemporary approaches to second language acquisition, v. 9, p. 199, 2013. 
DUSSIAS, Paola E. Parsing a first language like a second: The erosion of L1 parsing strategies in Spanish-English bilinguals. International Journal of Bilingualism, v. 8, n. 3, p. 355-371, 2004. https://doi.org/10.1177/13670069040080031001

ECKE, Peter. Language attrition and theories of forgetting: A cross-disciplinary review. International Journal of Bilingualism, v. 8, n. 3, p. 321-354, 2004. https://doi.org/10.117 $7 / 13670069040080030901$

ELLIS, Nick. C. The dynamics of language use, language change, and first and second language acquisition. Modern Language Journal, v. 41, n.3, p. 232-249, 2008.

FINCH, Andrew E. Complexity in the language classroom. Secondary Education Research, v. 47, p. 105-40, 2001.

FLEGE, James E. The production of "new" and "similar" phones in a foreign language: Evidence for the effect of equivalence classification. Journal of Phonetics, v. 15, p. 47-65, 1987. https://doi.org/10.1016/0167-6393(87)90025-2

Second language speech learning: Theory, findings, and problems. In: STRANGE, Winifred (Org.). Speech Perception and Linguistic Experience: Issues in cross-language research, 1995. p. 233-277.

Assessing constraints on second-language segmental production and perception. In: MEYER, Niels Olaf; SCHILLER, Antje (Org.). Phonetics and Phonology in Language Comprehension and Production, Differences and Similarities. Berlin: Mouton de Gruyter, 2003. p. 319-355.

Interactions between the native and second-language phonetic systems. In BURMEISTER, Petra; PISKE, Thorsten; ROHDE, Andreas (Org.). An Integrated View of Language Development: Papers in Honor of Henning Wode. Trier: Wissenschaftlicher Verlag, 2002. p. 217-244

. Language contact in bilingualism: Phonetic system interactions. In: COLE, Jennifer; HUALDE. José Ignacio (Org.). Laboratory phonology, 9. Berlin: Walter de Gruyter, 2007. p. 353-382.

FLEGE, James E.; EEFTING, Wieke. Cross-language switching in stop consonant perception and production by Dutch speakers of English. Speech Communication, v. 6, n. 3, p. 185-202, 1987.

FLEGE, James E.; HILLENBRAND, James. Limits on phonetic accuracy in foreign language production. Journal of the Acoustical Society of America, v. 76, p. 708-721, 1987.
FRANÇA, K. A aquisição da aspiração das plosivas surdas do inglês por falantes do português brasileiro: implicações teóricas decorrentes de duas diferentes formas de descrição dos dados. 2011. 112 fl. Dissertação (Mestrado em Letras) - Universidade Católica de Pelotas, Pelotas, 2011

GEWEHR-BORELLA, Sabrina. A influência da fala bilíngue Hunsrückisch-Português Brasileiro na escrita de crianças brasileiras em séries iniciais. 2010. 205 fl. Dissertação (Mestrado em Letras) - Universidade Católica de Pelotas, Pelotas, 2010.

GIBSON, James J. The Ecological Approach to Visual Perception. Boston: Houghton Mifflin 1979.

GORAL, Mira. First language decline in healthy aging: Implications for attrition in bilingualism. Journal of Neurolinguistics, v. 17, n. 1, p. 31-52, 2004. https://doi. org/10.1016/S0911-6044(03)00052-6

GROSJEAN, François. The bilingual's language modes. In: NICOL, Janet (Org.). One Mind, Two Languages: Bilingual Language Processing. Blackwell, 2001. p. 1-22.

GUION, Susan. G. The vowel systems of Quichua-Spanish bilinguals: Age of acquisition effects on the mutual influence of the first and second languages. Phonetica, v. 60, n. 2 , p. $98-128,2003$

HARADA, Tetsuo. L2 influence on L1 speech in the production of VOT. In: ROMERO, Joaquín (Org.). Proceedings of the 15th International Congress of Phonetic Sciences, Barcelona: Causal Productions, 2003. p. 1085-1088.

HAUGEN, Einar. The ecology of language. In: FILL, Alwin; MÜHLHÄUSLER, Peter (Org.) The ecolinguistics reader. London: Continuum, 2001. p. 57-66.

HEINE, Bernd; KUTEVA, Tania. On contact-induced grammaticalization. Studies in language, v. 27, p. 529-572, 2007.

HERNANDEZ, Arturo, BATES, Elizabeth, AVILA, Luis. On-line sentence interpretation in Spanish-English bilinguals: What does it mean to be "in between"? Applied Psycholinguistics, v. 15, p. 417-446, 1994. https://doi.org/10.1017/S014271640000 686X

HOPP, Holger. Ultimate attainment at the interfaces in second language acquisition: Grammar and processing. 2007. 477fls. Tese (Doutorado) - University of Groningen, Groningen, 2007.

KÖPKE, Barbara. Neurolinguistic Aspects of Attrition. Journal of Neurolinguistics, v. 17 n. 1, p. 3-30, 2004. https://doi.org/10.1016/S0911-6044(03)00051-4 
KÖPKE, Barbara; SCHMID, Monica. Language Attrition: The Next Phase. In: SCHMID, Monica; KÖPKE, Barbara (Org.). Language Attrition: Interdisciplinary Perspectives on Methodological Issues. Amsterdam: John Benjamins, 2004. p. 1-43.

KUPSKE, Felipe. Imigração, Atrito e Complexidade: a produção das oclusivas surdas iniciais do inglês e do português por brasileiros residentes em Londres. 2016. 233fls. Tese (Doutorado em Letras) - Universidade Federal do Rio Grande do Sul, Porto Alegre, 2016.

KUPSKE, Felipe; ALVES, Ubiratã. A fala de imigrantes brasileiros de primeira geração em Londres como evidência empírica para a língua como um Sistema Adaptativo Complexo. ReVEL, v. 14, n. 27, p. 173-203, 2016.

LADEFOGED, Peter. Vowels and consonants. Phonetica, v. 58, n. 3, p. 211-212, 2001.

LARSEN-FREEMAN, Diane. Chaos / Complexity Science and Second Language Acquisition. Applied Linguistics, v. 18, n. 2, p. 141-165, 1997. https://doi.org/10.1093/applin/18.2.141

Complexity theory: a new way to think. Revista Brasileira de Linguística Aplicada. v. 13 n. 2, Belo Horizonte, p. 369-373, 2013.

LENNEBERG, Eric. Biological foundations of language. New York: Wiley, 1967.

LEE, Sueanns; IVERSON, Gregory. Stop consonant of English-Korean bilingual children. Bilingualism: Language and Cognition. v. 15 n. 2, p. 275-287, 2012. https://doi.org/ 10.1017/S1366728911000083

LISKER, Leigh; ABRAMSON, Arthur. A cross-language study of voicing in initial stops: Acoustical measurements. Word, v. 20, n. 3, p. 384-422, 1964. https://doi.org/10.1080/ 00437956.1964.11659830

LORD, Gillian. Second language acquisition and first language phonological modification. In: GARAVITO, Joyce (Org.). Selected proceedings of the 10th Hispanic Linguistics Symposium. Somerville: Cascadilla Proceedings Project, 2008, p. 184-193.

MACWHINNEY, Brian. Language Emergence. In: BURMEISTER, Petra; PISKE Thorsten; RHODE, Andreas (Org.). An Integrated View of Language Development. Papers in Honor of Henning Wode. Trier: Wissenschaftliche Verlag. 2002. p. 17-42.

MAJOR, Roy C. Losing English as a first language. The Modern Language Journal, v. 76, n. 2, p. 190-208, 1992. https://doi.org/10.1111/j.1540-4781.1992.tb01100.x

MAJOR, Roy. First language attrition in foreign accent perception. Journal of Bilingualism, v. 14, n. 2, p. 163-183, 2010. https://doi.org/10.1177/1367006910363063
MAJOR, Roy; BAPTISTA, Barbara. First language attrition in foreign accent detection. In: WATKINGS, Michael, RAUBER, Andreia, BAPTISTA, Barbara (Org.). Recent research in second language phonetics/phonology: Perception and production. Newcastle Upon Tyne: Cambridge Scholars, 2007. p. 256-269.

MERCER, Sarah. Towards a complexity-informed pedagogy for language learning. Revista Brasileira de Linguística Aplicada. v. 13, n. 2, p. 375-398, 2013. https://doi.org/10.1590/ S1984-63982013005000008

OPITZ, Cornelia. First language Attrition and Second Language Acquisition in a SecondLanguage Environment. 2011. 341 fl. Tese (Doutorado) - Trinity College, Dublin, 2011.

PAIVA, Vera Menezes. Linguagem e aquisição de segunda língua na perspectiva dos sistemas complexos In: BURGO, V. H.; FERREIRA, E. F.; STORTO, L. J. Análise de Textos Falados e Escritos: aplicando teorias. Curitiba: Editora CRV, 2011. p. 71-86.

PURPURA, James. The Oxford Online Placement Test: What does it measure and how? 2007. Availabe in: http://www.oxfordenglishtesting.com

SANCIER. Michelle L.; FOWLER, Carol A. Gestural drift in a bilingual speaker of Brazilian Portuguese and English. Journal of Phonetics, v. 27, n. 4, p. 421-436, 1997.

SCHOLL, Ana Paula. Proficiência autoavaliada através de um questionário de histórico de linguagem. 2016. 120fls. Dissertação (Mestrado em Letras) - Universidade Federal do Rio Grande do Sul, Porto Alegre, 2016.

SCHMID, Monica. The Role of L1 Use for L1 Attrition. In: KÖPKE, Barbara; SCHMID, Monica (Org.). Language Attrition - Theoretical perspectives. Amsterdam/Philadelphia: John Benjamins, 2007. p. 135-153. https://doi.org/10.1002/wcs.1218

First Language Attrition. WIREs Cognitive Science, v. 4, n. 2. p. 117-123, 2013.

SCHWARTZHAUPT, Bruno. Factors influencing Voice Onset Time: analyzing Brazilian Portuguese, English and interlanguage data. 2013. 65 fl. Trabalho de Conclusão de Curso - Universidade Federal do Rio Grande do Sul, Porto Alegre, 2013.

SIMON, Ellen. Laryngeal Stop Systems in Contact: Connecting Present-Day Acquisition Findings and Historical Contact Hypotheses. Diachronica, v. 28, n. 2, p. 225-254, 2011. https://doi.org/10.1075/dia.28.2.03sim

SIMON, Ellen; LEUSCHNER, Torsten. Laryngeal systems in Dutch, English, and German: a contrastive phonological study on second and third language acquisition. Journal of Germanic Linguistics, v. 22, n. 04, p. 403-424, 2010. https://doi.org/10.1017/ S1470542710000127 
SLOBIN, Dan. Language change in childhood and in history. In: MACNAMARA, John (Org.). Language Learning and Thought. London: Academic Press, 1977. p. 185-214.

VAN HELL, Janet G.; DIJKSTRA, Tom. Foreign language knowledge can influence native language performance in exclusively native contexts. Psyconomic Bulletin and Review, v. 9, p. 780-789, 2002. https://doi.org/10.3758/BF03196335

WERKER; Janet; BYERS-HEINLEIN, Krista. Bilingualism in infancy: First steps in perception and comprehension. Trends in Cognitive Sciences, v. 12, n. 4, p. 144-151, 2008. https://doi.org/10.1016/j.tics.2008.01.008

WILLIAMS, Garnett P. Chaos theory tamed. Washington: Joseph Henry Press, 1997.

YAVAS, Mehmet. Factors influencing the VOT of English long lag stops and interlanguage phonology. In: RAUBER, Andreia; WATKINS, Michael; BAPTISTA, Barbara (Org.). New Sounds 2007. International Symposium on the Acquisition of Second Language Speech, 5, Florianópolis: Anais... UFSC, 2008. p. 492-498.

YILMAZ, Gulsen; SCHMID, Monica. Second Language Development in a Migrant Context: Turkish community in the Netherlands. International Journal of the Sociology of Language, v. 236, p. 101-132, 2015.

ZIMMER, Marcia C.; ALVES, Ubiratã K. O impacto do bi/multilinguismo sobre o potencial criativo em sala de aula - uma abordagem via Teoria dos Sistemas Dinâmicos. Revista FAEEBA, v. 23, p. 77-90, 2014.

Recebido em 19/01/2017.

Aprovado em 15/06/2017. 